Institute of $\mathbf{F}_{\text {ood and }} \mathbf{A}_{\text {gricultural }} \mathbf{S}_{\text {ciences }}$

\title{
Florida Solid and Hazardous Waste Regulation Handbook: Residual Waste Disposal ${ }^{1}$
}

Michael T. Olexa, Aaron Leviten, and Kelly Samek ${ }^{2}$

\section{How May I Use Domestic Wastewater Residuals/Sludge?}

Domestic wastewater residuals (sludge) are solid, liquid, or semi-solid wastes generated from wastewater treatment plants. This waste is rich in nutrients and may be applied to farmland as a form of fertilizer. Applying sludge in such a way is technically disposing of waste and is regulated. DEP has established detailed regulations controlling the application of sludge to land. The regulations require all producers to classify their sludge based on the level of treatment it has received. Each class has different restrictions on use, with Class AA being least restrictive and Class $\mathrm{C}$ being most restrictive.

\section{What Are the Special Restrictions on Using Residuals?}

Class AA residuals are treated to the same level as Class A residuals but may contain particular elements only up to certain levels. Class A residuals are the most treated, then Class B, and finally Class C. This system allows residuals, which are safer because of more intensive treatment, to have more uses and fewer restrictions.

\section{What Methods of Residual Disposal Are Prohibited?}

General prohibitions on the disposal of residuals:

- Residuals may never be dumped into the ocean, surface or ground waters.

- Residuals containing hazardous wastes may never be applied to agricultural lands, and may require disposal under more restrictive, hazardous waste regulations.

- Depending upon the type of residuals and land involved, there may be waiting periods that must be observed before the public may be allowed access to any land to which sludge has been applied.

All Classes of residuals, except Class AA, are subject to the following restrictions:

- may not be applied closer than 3000 feet from a Class I water body, Outstanding Florida Water, or Outstanding National Resource Water.

1. This is EDIS document FE461, a publication of the Department of Food and Resource Economics, Florida Cooperative Extension Service, UF/IFAS, University of Florida, Gainesville, FL. Published December 2003. Please visit the EDIS website at http://edis.ifas.ufl.edu.

2. Michael T. Olexa, Professor in the Department of Food and Resource Economics and Director of the Agricultural Law Center, Florida Cooperative Extension Service, UF/IFAS, University of Florida, Gainesville, FL, and Member of the Florida Bar and Chair of the Agricultural Law Committee of the Florida Bar; Aaron Leviten, Attorney in Orlando and guest lecturer on pesticide litigation at the University of Florida; and Kelly Samek, 2003 graduate of the Levin College of Law at the University of Florida.

The Institute of Food and Agricultural Sciences is an equal opportunity/affirmative action employer authorized to provide research, educational information and other services only to individuals and institutions that function without regard to race, color, sex, age, handicap, or national origin. For information on obtaining other extension publications, contact your county Cooperative Extension Service office. Florida Cooperative Extension Service/Institute of Food and Agricultural Sciences/University of Florida/Christine Taylor Waddill, Dean. 
- may not be applied closer than 200 feet from any other surface water except self-contained canals or irrigation structures which will not discharge from the site (this distance may be reduced to 100 feet under certain conditions).

- may not be applied closer than 300 feet from any shallow private water supply well.

- may not be applied closer than 500 feet from any shallow public water supply well.

- may not be applied if the soil $\mathrm{pH}$ is lower than 6.5 .

- may not be applied during rains that cause runoff from the site.

- may not be applied when soils are saturated.

- may not be applied if the grade of the land is greater than 8 percent.

- must be applied with appropriate techniques and equipment.

\section{What Are the Classes of Residuals?}

Class AA residuals:

- may be used for the cultivation of tobacco or leafy vegetables, and are exempt from most other restrictions.

Class A residuals:

- may be used on playgrounds, parks, golf courses, lawns, hospital grounds, or other unrestricted access areas.

Class B residuals:

- may be applied to sod farms, pasture lands, forests, limited access highways or roadways, and plant nurseries.

- may not be used on playgrounds, parks, golf courses, lawns, hospital grounds, or other unrestricted access areas.

- may be used on agricultural land, but may require a waiting period after the residuals are applied, before crops may be grown or harvested (orchard tree crops that do not come in contact with the residuals are exempt).

- The waiting period is 18 months for root crops and fruits and vegetables that touch the soil and are to be consumed raw.

- The waiting period is 30 days for fruits and vegetables that do not touch the soil and are to be consumed raw.

- The waiting period is 30 days before pasture vegetation may be cut or used for grazing.

- The waiting period is 12 months before the public may have contact with the area.

Class $\mathrm{C}$ residuals:

- are subject to all of the restrictions of class B residuals, with a few changes:

- The waiting period is 60 days for fruits and vegetables that do not touch the soil and are to be consumed raw.

- Class $\mathrm{C}$ residuals must not be applied within 500 feet of a building occupied by the general public.

- This restriction may be reduced to 100 feet if the residuals are injected into the soil.

\section{Acknowledgments}

The authors are indebted to the personnel of both state and federal agencies who gave their time and advice in the preparation of this handbook. The authors are also indebted to the following University of Florida personnel for a review and critique of the first draft of this publication: Dr. Thomas Dean, Pesticide Education Specialist, and Dr. Norman Nesheim, Pesticide Information Coordinator. Special recognition is also due to Mr. Richard Budell of the Office of Agricultural Water Policy of the Florida Department of Agriculture and Consumer Services for providing funds for the development of this handbook.

This handbook is designed to provide an accurate, current, and authoritative summary of the principal Florida laws that directly or indirectly relate 
to agriculture. It should provide a basic overview of the many rights and responsibilities farmers and farmland owners have under Florida laws. The reader is provided information about these rights and responsibilities and the appropriate contacts for more detailed information. However, the reader should be aware that because the laws, administrative rulings, and court decisions on which this publication is based are subject to constant revision, portions of this publication could become outdated at any time. Many details of cited laws are also left out due to space limitations.

This handbook is distributed with the understanding that the authors are not engaged in rendering legal or other professional advice and the information contained herein should not be regarded or relied upon as a substitute for professional advice. It is not all-inclusive in providing information to achieve compliance with laws and regulations governing the practice of agriculture. For these reasons, the use of these materials by any person constitutes an agreement to hold harmless the authors, UF/IFAS, the Agricultural Law Center, and the University of Florida for any liability claims, damages, or expenses that may be incurred by any person as a result of reference to or reliance upon the information contained in this publication. 